\title{
Development of Russian Resource-Type Regions: Geography vs. Institutions?
}

\author{
Margarita V. Kurbatova*a, Elena S. Kagan ${ }^{\text {, }}$ \\ Sergey N. Levin' and Dmitry V. Kislitsyn ${ }^{\mathrm{d}}$ \\ ${ }^{a}$ Siberian Federal University \\ Krasnoyarsk, Russian Federation \\ ${ }^{b}$ Kemerovo State University \\ Kemerovo, Russian Federation \\ ${ }^{c}$ Financial University under the Government of the Russian Federation \\ Plekhanov Russian University of Economics \\ Moscow, Russian Federation \\ ${ }^{d}$ National Research University - Higher School of Economics \\ St. Petersburg, Russian Federation
}

Received 20.07.2021, received in revised form 10.09.2021, accepted 10.11.2021

\begin{abstract}
The paper examines the dynamics of the level of resource dependence in the resource-type regions of Russia from 2005 to 2017 . The classification of regions is based on the authors' two-factor classification model using the share of the extractive sector in the GRP and the ratio of the extractive sector to the manufacturing industry. Exploiting the method of fuzzy classification and calculating a comprehensive assessment of resource dependence, the classification regions are classified on a scale of continuous values, which makes it possible to assess the level of resource dependence of the regions of the Russian Federation and their grouping. The dynamics of the level of resource dependence is monitored and the regions that have made transitions from one selected group to another are distinguished. The results obtained indicate that in the period under consideration there was an increase in the level of resource dependence. For most of the resource-type regions, the level of resource dependence has increased, the number of resource-type regions has grown from 22 to 27 . An analysis of the case studies of individual regions shows that the policy of the federal center and the largest Russian companies, often state-owned, was in most cases more significant than the policy of regional authorities. The case of Russia, therefore, corresponds to the patterns described in the literature investigating the influence of geography and institutions on development at the subnational level: geographic factors play a decisive role in the development of regions, the role of subnational institutions is small. Differences at the subnational level in such institutional factors as the protection of property rights or regulatory efficiency are not decisive in attracting investment; priorities formed at the national level play a decisive role. The ability of regional authorities to influence
\end{abstract}

\footnotetext{
(C) Siberian Federal University. All rights reserved

* Corresponding author E-mail address: kurbatova-07@mail.ru ORCID: 0000-0002-7017-5266 (Kurbatova)
} 
the development of the region comes down mainly to the effective integration of the federal center into the projects.

Keywords: resource-type region, resource dependence, resource abundance, resource regime, fuzzy classification, typology of Russian regions, economic development of regions, spatial development, subnational institutions, natural resources.

This research is supported by the Russian Foundation for Basic Research (RFBR), Grant № 19-010-00244 «Institutional setup of the labor market in resource-type regions».

Research area: economics.

Citation: Kurbatova, M.V., Kagan, E.S., Levin, S.N., Kislitsyn, D.V. (2021). Development of Russian resource-type regions: geography vs. institutions? J. Sib. Fed. Univ. Humanit. soc. sci., 14(12), 18081819. DOI: $10.17516 / 1997-1370-0860$

\title{
Развитие российских регионов ресурсного типа: география vs. институты?
}

\author{
М.В. Курбатова ${ }^{a}$, Е.С. Каган ${ }^{6}$, \\ С.Н.Левинв, Д.В. Кислицынг \\ ${ }^{a}$ Сибирский федеральный университет \\ Российская Федерация, Красноярск \\ ${ }^{\sigma}$ Кемеровский государственный университет \\ Российская Федерачия, Кемерово \\ ${ }^{8}$ Финансовый университет при Правительстве РФ, \\ Российский экономический университет имени Г. В. Плеханова \\ Российская Федерачия, Москва \\ ' Национальный исследовательский университет \\ «Высшая школа экономики» \\ Российская Федерачия, Санкт-Петербург
}

\begin{abstract}
Аннотация. В статье рассмотрена динамика уровня ресурсной зависимости российских регионов ресурсного типа с 2005 по 2017 г. Типологизация регионов дана на основе авторской двухфакторной модели классификации, базирующейся на доле добывающего сектора в ВРП и соотношении добывающего сектора к обрабатывающей промышленности. С помощью метода нечеткой классификации и расчета комплексной оценки ресурсной зависимости регионы классифицируются по шкале непрерывных величин, что позволяет получить оценку уровня их ресурсной зависимости и группировку. Отслежена динамика уровня ресурсной зависимости и выделены регионы, осуществившие переходы из одной выделенной группы в другую. Полученные результаты свидетельствуют, что в рассматриваемом периоде для большей части ресурсных регионов уровень такой зависимости увеличился, а количество регионов ресурсного типа выросло с 22 до 27. Анализ кейсов отдельных регионов свидетельствует, что политика федерального центра и крупнейших российских компаний, зачастую государственных, была
\end{abstract}


существенно более значимой, чем политика региональных органов власти. Случай России, таким образом, соответствует закономерностям, описанным в литературе, исследующей влияние географии и институтов на развитие на субнациональном уровне: решающую роль в развитии регионов играют географические факторы, роль субнациональных институтов мала. Различия на субнациональном уровне в таких институциональных факторах, как защита прав собственности или регуляторная эффективность, не являются определяющими в привлечении инвестиций, решающую роль играют приоритеты, сформированные на национальном уровне. Возможность повлиять на развитие региона для местных органов власти сводится главным образом к эффективному встраиванию в проекты федерального центра.

Ключевые слова: регион ресурсного типа, ресурсная зависимость, ресурсная обеспеченность, ресурсный режим, нечеткая классификация, типологизация регионов России, экономическое развитие регионов, пространственное развитие, субнациональные институты, природные ресурсы.

Исследование выполнено при финансовой поддержке РФФИ в рамках научного проекта 19-010-00244 «Институциональная организация рынка труда в регионах ресурсного типа».

Научная специальность: 08.00.01 - экономическая теория.

\section{Introduction}

Resource-type regions - regions whose economy is based on the mining and manufacturing industries of the first redistribution play a special role in the Russian economy. It is the extraction of oil, gas, coal, ferrous and non-ferrous metallurgy that determine the place of Russia in the global economic system (Levin et al., 2015). The development of Russian resource-type regions is decisive for the development of the Russian economy.

The development of territories specializing in mining is traditionally explained in terms of two approaches: resource abundance and resource dependence. Resource abundance is an exogenous factor, which is determined by the geographic location and available natural resource base; it does not depend either on the institutional environment or on the quality of economic policy. On the contrary, resource dependence is endogenous, it is formed not only under the influence of resource abundance, but also under the influence of the institutional environment and economic policy.

The regions of Russia are significantly differentiated both by the level of resource abundance and by the level of resource dependence. The classification of Russian regions according to these criteria is an important research objective; the possibility of choosing the most effective economic policy, both at the level of the federal center and the level of the constituent entities of the Federation, depends on its solution.

In this paper, a two-factor model of the classification of regions based on such criteria as the share of the extractive sector in the GRP and the ratio of the extractive sector to the manufacturing industry will be proposed. Based on the classification model, a comprehensive assessment of the level of resource dependence will be calculated for the period from 2005 to 2017. Thus, it becomes possible not only to classify regions according to the level of resource dependence but also to analyze trends: to single out regions that have dropped out of the corresponding groups or joined them, regions that have shown an increase or decrease in the indicator of resource dependence and make assumptions about factors that caused these changes.

\section{Theoretical framework}

Discussion about the reasons for different trajectories of economic development of countries and regions in modern economic theory 
can largely be reduced to a discussion of the relative importance of institutional and geographical factors. The so-called dispute «geography versus institutions» was initiated by the works of S. Knack and F. Keefer (Knack \& Keefer, 1995) and P. Mauro (Mauro, 1995), who demonstrated the importance of institutions for economic development, but this dispute became especially heated after the publication by Sachs (2001), who argued the leading role of geographic factors. Sachs argued that countries with moderate climates and coastal countries have significant advantages, which historically led to higher growth rates of these countries and higher levels of development. Acemoglu, Johnson and Robinson (Acemoglu et al., 2001b), in turn, focused on the institutional factors that determined different development trajectories. Acemoglu et al. (2001a) showed that countries and regions that were rich in 1500 became relatively poor in 1995 , and vice versa. This refutes the notion of the static influence of geography on economic development. The works of D. Rodrik, A. Subramanian and F. Trebbie (Rodrik et al., 2004), and W. Easterly and R. Levine (2003) have also demonstrated that geographic factors may influence the formation of institutions, but when institutional factors are taken into account, there is no effect of geographic factors on long-term economic development.

In contrast to the extensive literature on cross-country comparisons, the literature examining the relationship between geography, institutions, and development at the subnational level is relatively scarce. Gennaioli et al. (2013) highlighted the significant effect of geographic factors and the lack of a significant effect of institutions at the subnational level. Dell et al. (2009), Nordhaus (2006), and Warner (2002) have shown a significant effect of geographic factors on economic development. T. Mitton (Mitton, 2016) demonstrated that geographical factors have a significant impact on development (including the provision of natural resources - a positive one), while institutional factors (protection of property rights, regulatory efficiency, etc.) do not have such an effect. Thus, the results at the subnational level differ significantly from the results at the na- tional level - if at the national level there is convincing evidence that institutional differences are the main factors determining different levels of economic development of countries, then at the subnational level, geographic factors play a leading role, namely, they explain the differences in economic development between regions.

What explains the difference in the roles of geography and institutions at the national and subnational levels? T. Mitton explains this by the domination of national institutions over subnational ones. In his study, national institutions have a much greater explanatory power than subnational. In addition, it shows that if a country has a sufficiently high level of autonomy, the differences in regional institutions have an impact on economic development. The key mechanism through which autonomy allows regional institutions to influence the economic development of regions is fiscal powers. Thus, the role of subnational institutions in such countries as the United States, India, Brazil, or Argentina, in which subnational units spend 40 to $70 \%$ of the total expenditures of consolidated budgets is high (Mitton, 2016).

Long-term economic development does not have one reason, this observation is especially true for the interaction of geography and institutions. Moreover, geographic characteristics are one of the factors determining the formation of specific institutions. An example of such a complex interaction is the resource dependence of resource-rich regions. Resource dependence is the result of a complex interaction between geography (resource abundance) and the institutional environment. The extensive literature on the impact of resource abundance and resource dependence on economic development (the so-called "resource curse» literature) tends to show a positive relationship between resource abundance and economic development (Van der Ploeg, 2011) and a negative relationship between resource dependence and economic development (Sachs \& Warner, 1995).

Studies devoted to the «resource curse» at the subnational level name three groups of mechanisms through which resource abundance and resource dependence can influence 
the development of territories: direct impact, mechanisms associated with government spending, and regional spillovers. Direct impact refers to the expenditures of mining companies in the production areas. The increase in production causes both positive effects, such as an increase in local budget revenues and an increase in employment in local small businesses, and negative ones, such as an increased strain on local social infrastructure. Regional spillovers mean the version of the Dutch disease at the regional level: a resource boom leads to a sharp rise in prices in the local market and, as a result, resources flow from the uncompetitive local manufacturing industry to the service sector. Finally, the mechanisms associated with government spending mean the redistributive activity of the state and the interaction of the national and subnational budgets. Depending on the type of tax regime, most of the resource rent may be paid to the national government or remain at the local level. Studies using data from countries with different tax regimes show that significant revenues of local budget from mining can stimulate development at the local level, but this effect is not guaranteed - resource rent can provoke corruption, ineffective government spending, and conflicts between levels of government (Arellano-Yanguas, 2011; Caselli \& Michaels, 2013; Cust \& Rusli, 2014; Perry \& Olivera, 2009). Thus, we can talk about the convergence of the conclusions of the two branches of literature, namely literature on «resource curse» at the subnational level and literature on the role of geography and institutions at the subnational level: the role of subnational institutions is important if regions have sufficient fiscal authority.

\section{Statement of the problem}

Since resource dependence is an important factor determining development at the subnational level, it becomes necessary to assess the level of this indicator for Russian regions and to study its dynamics. This is even more important because Russia is characterized by a high degree of spatial inequality, although, as N. V. Zubarevich notes, large countries of catching-up development, such as China or Brazil, have no less level of differ- ences between subnational units (Zubarevich, 2009). The long-term development of Russian resource-type regions is largely determined by the level of resource dependence. In this article, we will answer the question of how stable this level is if there is an increase or decrease in the level of resource dependence of Russian regions of the resource type, and also highlight the features of the regions that experienced a significant increase or decrease in the level of resource dependence in the period from 2005 to 2017 .

\section{Data and methods}

The assessment of the level of resource dependence of Russian regions and their classification according to this criterion has been undertaken by many researchers. At the same time, most of the proposed approaches are single-factor (Belousova, 2015; Ilyina, 2013; Kagan \& Goosen, 2017) (regions are classified by the share of mining in the gross regional product). This approach does not fully expose the problem of resource dependence: a high share of mining in GRP can be due to both an abundance of resources with a high degree of development of other sectors, and the phenomenon of resource dependence, which manifests itself in a low level of development of the nonresource part of the economy.

A two-factor model for the typology of Russian regions (taking into account the share of the extractive sector in the GRP and the ratio of the extractive and manufacturing industries) was proposed by I.P. Glazyrina, E. A. Klevakina (Glazyrina \& Klevakina, 2013) and M. V. Kurbatova et al., 2019. A feature of the approach implemented in the work of Kurbatova et al. is the use of the fuzzy classification method for a more substantiated typology of regions on a scale of continuous values.

This study also uses a quantitative assessment of the level of resource dependence on a scale of continuous values. At the first stage, a fuzzy classification of the subjects of the federation is carried out according to two indicators - the share of the extractive sector in the GRP and the ratio of the extractive sector to the manufacturing industry. The data source is the Rosstat compilations «Regions of Russia. 
Socio-economic Indicators». Each of the indicators is presented in the form of a linguistic variable with a given term-set: $\mathrm{T} 1$ - low, T2 - medium, T3 - high (Pegat, 2013). The membership functions of the terms were trapezoidal. The value of the main points of these functions is determined based on expert assessments. Thus, when dividing into levels according to the two selected criteria of resource dependence (the share of the extractive sector in the gross regional product of the region and the ratio of the share of the extractive sector to the manufacturing industry), 9 possible classes are distinguished: low/low, low/medium, low/ high, medium/low, medium/medium, medium/ high, high/low, high/medium, high/high. For each subject of the federation, the degree of its belonging to each of the 9 classes is determined using the T-norm min. from the range $[0 ; 1]$. Russian regions were characterized by the characteristics of either one or several classes at once (2 or 4).

At the second stage, a comprehensive assessment of the resource dependence of the regions is calculated. For these purposes, such apparatus of fuzzy inferences as the 0 -order Sugeno method was used (Onar et al., 2018). Each class is assigned a constant, the value of which can vary from 0 to 10 . This constant is an expert judgment and characterizes the degree of resource dependence of a given class. The calculation of a comprehensive assessment of resource dependence for each constituent entity of the Federation is carried out on the basis of its degrees of belonging to each of the 9 classes and expert assessments presented using the centroid method (Borisov et al., 2012). Thus, each subject of the Federation is assigned a number from 0 (no resource dependence) to 10 (high resource dependence).

\section{Discussion}

Kurbatova et al. (2019) present the results of the classification of Russian regions for 2016. In this work, estimates of the level of resource dependence are given in the time interval from 2005 to 2017. Table 1 presents the results for the final year of the period under review.

The dynamics of the level of resource dependence is presented in Table 2 (regions are ranked by the level of resource dependence in 2017). In general, at this time interval, we see an increase in the level of resource dependence. For most of the resource regions, the level of resource dependence has increased, the number of resource-type regions has increased from 22 to 27 .

The most stable group is a group of regions with a very high level of resource dependence. At the beginning of the period, there were five such regions, two were added - the Sakhalin Oblast (from 2006-2007) and the Chukotka Autonomous Okrug (from 2007-2008). In both cases, the reason was the implementation of large-scale production projects. Oil and gas production has become the backbone of the Sakhalin Oblast's economy since the launch of the giant Sakhalin 1 (Chayvo, Odoptu, and Arkutun-Dagi fields) and Sakhalin-2 (PiltunAstokhskoye and Lunskoye fields), as well as the construction of Russia's first plant for the production of liquefied natural gas (produces $4 \%$ of the world's LNG). The core of the mining industry of the Chukotka Autonomous Okrug is ore gold mining projects carried out by the Chukotka Mining and Geological Company (Kupol deposit) and Severnoye Zoloto (Dvoinoe deposit), Mayskoye Gold Mining Company LLC, part of the Polymetal group of companies (Mayskoye deposit), OJSC Mine Karalveem (deposit Karalveem) and LLC Mine Valunisty (deposit Valunistoe).

The group of regions with a predominance of the extractive industries over the processing industries with an average share of the extractive industries in the GRP was the least stable. At the beginning of the period, two regions corresponded to the selected characteristics - the Chechen Republic (2005-2007) and the Republic of Ingushetia (2005-2006). Both regions left the group by 2017. This is due to the depletion of deposits, which began back in the Soviet years. High criminalization of oil production and the use of barbaric methods of production in the 1990s became another reason why, after a temporary increase in production in the 2000 s, oil production began to steadily decline in these North Caucasian regions.

At the same time, the group of regions with a predominance of extractive industries over 
Table 1. Grouping of regions by the level of resource dependence (according to data from 2016-2017)

\begin{tabular}{|c|c|c|c|c|}
\hline Region groups & $\begin{array}{l}\text { Share of } \\
\text { extractive } \\
\text { industries } \\
\text { in GRP,\% }\end{array}$ & $\begin{array}{l}\text { The ratio of the shares } \\
\text { of the extractive and } \\
\text { processing industries } \\
\text { in the GRP, times }\end{array}$ & $\begin{array}{l}\text { Compre- } \\
\text { hensive } \\
\text { assessment } \\
\text { of resource } \\
\text { dependence }\end{array}$ & Subjects of the Federation \\
\hline $\begin{array}{l}\text { Very high level of re- } \\
\text { source dependence }\end{array}$ & $38.9-74.5$ & more than 22.3 times & $9.25-10$ & $\begin{array}{l}\text { Yamal-Nenets Autonomous } \\
\text { Okrug, Chukotka Autono- } \\
\text { mous Okrug, the Republic } \\
\text { of Sakha (Yakutia), Khanty- } \\
\text { Mansi Autonomous Okrug- } \\
\text { Yugra, Yamal-Nenets Au- } \\
\text { tonomous Okrug, Magadan } \\
\text { Region, Sakhalin Region. }\end{array}$ \\
\hline $\begin{array}{l}\text { The predominance of } \\
\text { the extractive indus- } \\
\text { tries over the process- } \\
\text { ing industries with an } \\
\text { average share of the } \\
\text { extractive industries } \\
\text { in the GRP }\end{array}$ & $15.8-28.2$ & $4.65-17.2$ & $8.13-8.73$ & $\begin{array}{l}\text { The Republic of Tyva, Astra- } \\
\text { khan Oblast, Amur Oblast }\end{array}$ \\
\hline $\begin{array}{l}\text { High level of resource } \\
\text { dependence }\end{array}$ & $14.0-35.1$ & $1.8-4$ & $7.26-7.91$ & $\begin{array}{l}\text { Zabaykalsky Krai, Komi Re- } \\
\text { public, Tomsk Oblast, Oren- } \\
\text { burg Oblast, Irkutsk Oblast, } \\
\text { Kemerovo Oblast }\end{array}$ \\
\hline $\begin{array}{l}\text { The average level of } \\
\text { resource dependence }\end{array}$ & $23.2-7.7$ & $0.41-1.78$ & $5.44-6.76$ & $\begin{array}{l}\text { Murmansk Oblast, the Re- } \\
\text { public of Tatarstan, Udmurt } \\
\text { Republic, Tyumen Oblast } \\
\text { without Autonomous Dis- } \\
\text { tricts, the Republic of Kha- } \\
\text { kassia, Kursk Oblast, the } \\
\text { Republic of Karelia, Samara } \\
\text { Oblast, Krasnoyarsk Krai, } \\
\text { Perm Krai, Belgorod Oblast. }\end{array}$ \\
\hline $\begin{array}{l}\text { Low level of resource } \\
\text { dependence }\end{array}$ & & & $0-4.23$ & 58 regions \\
\hline
\end{tabular}

processing industries with an average share of extractive industries in GRP was replenished by the Astrakhan Oblast (from 2011), as well as the Republic of Tyva (from 2014) and the Amur Oblast (from 2009). The rapid development of the oil and gas industry in the Astrakhan Oblast is associated with offshore projects on the shelf of the Caspian Sea. In particular, the launch in 2010 of the Yuri Korchagin field of the Lukoil company led to a twofold increase in oil production. The Republic of Tyva is characterized by the richest reserves of coal and polymetallic ores, but only relatively recently these deposits have turned out to be attractive for development from a commercial point of view. This is due, among other things, to active support measures from the federal government, in particular, the construction of the KyzylKuragino railway line. The Amur Oblast possesses significant reserves of alluvial and ore gold, gold production fluctuates significantly depending on the dynamics of world prices for this metal. In general, this group of regions is characterized by a transitional state, when the commissioning or disposal of capacities in the extractive or manufacturing industries leads to 
Table 2. Dynamics of the level of resource dependence

\begin{tabular}{|c|c|c|c|c|c|}
\hline Region & $\begin{array}{c}\text { Comprehensive } \\
\text { assessment on } \\
2005\end{array}$ & $\begin{array}{l}\text { Comprehen- } \\
\text { sive assess- } \\
\text { ment for } 2017\end{array}$ & $\begin{array}{l}\text { Change in the } \\
\text { comprehensive } \\
\text { assessment }\end{array}$ & $\begin{array}{l}\text { Group in } \\
2005\end{array}$ & $\begin{array}{l}\text { Group in } \\
2017\end{array}$ \\
\hline Yamal-Nenets Autonomous Okrug & 9.9 & 10.0 & 0.05 & 1 & 1 \\
\hline $\begin{array}{l}\text { Khanty-Mansi Autono- } \\
\text { mous Okrug - Yugra }\end{array}$ & 10.0 & 10.0 & 0.00 & 1 & 1 \\
\hline Nenets Autonomous Okrug & 10.0 & 10.0 & 0.00 & 1 & 1 \\
\hline Sakhalin Oblast & 8.7 & 10.0 & 1.24 & 2 & 1 \\
\hline The Republic of Sakha (Yakutia) & 9.5 & 9.7 & 0.24 & 1 & 1 \\
\hline Chukotka Autonomous District & 6.9 & 9.6 & 2.77 & 2 & 1 \\
\hline Magadan Oblast & 9.2 & 9.5 & 0.28 & 1 & 1 \\
\hline Astrakhan Oblast & 0.0 & 9.5 & 9.50 & 5 & 2 \\
\hline The Republic of Tyva & 4.1 & 9.2 & 5.09 & 5 & 2 \\
\hline Amurskaya Oblast & 4.1 & 7.0 & 2.99 & 5 & 2 \\
\hline Zabaykalsky Krai & 5.6 & 8.5 & 2.94 & 4 & 3 \\
\hline Komi Republic & 7.9 & 8.1 & 0.16 & 3 & 3 \\
\hline Tomsk Oblast & 7.6 & 7.7 & 0.12 & 3 & 3 \\
\hline Orenburg Oblast & 7.7 & 7.9 & 0.20 & 3 & 3 \\
\hline Irkutsk Oblast & 0.0 & 7.5 & 7.52 & 5 & 3 \\
\hline Kemerovo Oblast & 7.0 & 7.8 & 0.83 & 1 & 3 \\
\hline Murmansk Oblast & 4.1 & 6.3 & 2.14 & 5 & 4 \\
\hline The Republic of Tatarstan & 7.3 & 6.8 & -0.43 & 4 & 4 \\
\hline Udmurtia & 6.6 & 6.5 & -0.11 & 4 & 4 \\
\hline Krasnoyarsk Krai & 0.0 & 6.1 & 6.13 & 5 & 4 \\
\hline Perm Krai & 5.7 & 6.1 & 0.38 & 4 & 4 \\
\hline Samara Oblast & 3.2 & 6.0 & 2.82 & 5 & 4 \\
\hline The Republic of Khakassia & 2.4 & 6.0 & 3.59 & 5 & 4 \\
\hline Belgorod Oblast & 6.1 & 6.0 & -0.13 & 4 & 4 \\
\hline The Republic of Karelia & 6.2 & 6.1 & -0.12 & 4 & 4 \\
\hline Kursk Oblast & 6.6 & 5.4 & -1.22 & 4 & 4 \\
\hline The Chechen Republic & 8.9 & 3.0 & -5.89 & 2 & 5 \\
\hline The Republic of Ingushetia & 9.0 & 0.0 & -9.00 & 2 & 5 \\
\hline
\end{tabular}

the transition of the region to a group with a higher or lower level of resource dependence.

The group of regions with a high level of resource dependence during the study period lost two regions, which moved into the group with a very high level of resource dependence (Sakhalin Oblast and Chukotka Autonomous Okrug) and was replenished by two regions the Zabaykalsky Krai (since 2015) and the Irkutsk Oblast (low level) (resource dependence until 2010, the average level of resource dependence - until 2014). The new development of mining projects in the Siberian regions is associated with active measures by the federal center and the largest Russian companies. In the case of the Irkutsk Oblast, this is the development of the Verkhnechonskoye field by Rosneft, as well as the development of the Kovykta field and the construction of the Power of Siberia gas pipeline by Gazprom. The construction 
of the Naryn-Gazimurskiy Plant railway plays an important role in the development of the raw material base of the Zabaykalsky Krai.

Regions entered the group of regions with an average level of resource dependence during the study period (5) and exited (3), as a result, the size of the group increased from 9 to 11 . The class of resource dependence increased in the Zabaykalsky Krai, decreased in the Republic of Kalmykia (2006-2007) and the Republic of Bashkortostan (2009-2010). New resourcetype regions entered the group - the Samara Oblast (from 2007-2008), the Murmansk Oblast (from 2008), the Republic of Khakassia (2008-2009), and the Krasnoyarsk Krai (from 2010).

Having analyzed the changes in the level of resource dependence of Russian regions in the considered time interval, we can draw several conclusions. First, the level of resource dependence of Russian regions, expressed in the authors' comprehensive assessment, has undergone certain changes. The number of resource-type regions has grown, the level of resource dependence has increased on average. Second, the dynamics of resource dependence is characterized by significant inertia. The implementation of large-scale oil production projects has had an impact on the development of the region for decades to come. Third, the policy of the federal center and the largest Russian companies, often state-owned, turns out to be more significant than the policy of regional authorities. It was the consistent efforts of the federal center to develop the mineral reserves of the regions of Eastern Siberia that led to the movement of several regions into groups with high or very high resource dependence. The active policy of the regional authorities can play a certain role, as it happened in the case of the Krasnoyarsk Krai or the Astrakhan Oblast, where regional authorities sought to build partnerships with the largest federal companies, however, the role of regional authorities is low and continues to decline.

\section{Conclusion}

For Russia, whose regions are significantly different both in terms of the level of resource abundance and the level of resource dependence, regions classification for assessing the differences in the institutional organization is an important research problem. From a normative point of view, the classification of regions according to the degree of resource dependence is necessary to substantiate the differentiated policy of the federal center towards regional socio-economic development. From a positive point of view, the research interest is the identification of the key factors influencing the formation of resource dependence, and, therefore, the long-term development of the regions.

The results obtained indicate that in the period under review, the level of resource dependence was determined by the interaction of geographical factors and the policy of the federal center. It seems that this can be explained by the changes that have occurred in the position of regional authorities in the past 20 years. In the 1990s, the resource regions' power structures' leaders possessed significant political resources of their own, acting in the role of subnational «rulers,» positioning themselves as representatives of the interests of the region as a territorial corporation. During this period, resource-type regions turned into relatively autonomous political and economic systems, and their leaders, as leaders of territorial corporations, took on the role of engaged actors connecting political, administrative, and economic functions. A striking example of such a system was the Kuzbass, where the politically influential administration headed by A. G. Tuleyev formed a system of agreements with federal-level companies and business in general (Kurbatova \& Levin, 2010) to obtain additional budget revenues.

In the $2000 \mathrm{~s}$, formal and informal centralization of political and economic bargaining happened. As a result, «the power vertical» was formed. It is not a single vertical of administrative control, but a pyramid of bargaining between the «ruling group» as its central actor, federal companies, politicized administrators of the federal and regional levels. The most important area of formal and informal centralization of the political and economic system was strengthening of the control of the ruling group over the largest 
entrepreneurs and leaders of regional power structures, which at some point led to its qualitative shift. At the level of regional power, subnational rulers rooted in their territories have been replaced in most cases by politicized administrators - representatives of the federal center. The political resource of these administrators is determined by their ties to the ruling group and various groups of politicized administrators and companies at the federal level. Accordingly, the comparative advantages of the governors who represent the federal center are not associated with the creation of a local institutional environment for attracting independent investors, but with the possibility of integrating into federal projects. Under these conditions, the significance of institutional differences at the regional level decreases. As a result, there is a desubjectivisation of resource-type regions in the national political and economic system. Governors-representatives of the federal center are not bearers of regional interests, the resource-type region is turning from an active participant into a platform for political and administrative bargaining between various actors at the federal level. Opportunities for the successful development of the region turn out to be associated with the development of institutions at the regional level, and with effective lobbying of the region's interests at the federal level.

The Russian case, thus, follows the patterns described in the literature exploring the impact of geography and institutions on development at the subnational level (ArellanoYanguas, 2011; Caselli \& Michaels, 2013; Cust \& Rusli, 2014; Perry \& Olivera, 2009). Geographic factors (resource abundance, proximity to ports, and sales markets) play a decisive role in the development of regions; the role of subnational institutions is small. A plausible explanation of the situation is proposed by T. Mitton (Mitton, 2016): the role of regional institutions is not significant because of the dominance of national-level institutions, lack of autonomy in the decision-making process, and, above all, insufficient fiscal powers. Differences at the subnational level in such institutional factors as protection of property rights or regulatory efficiency are not decisive in attracting investment, priorities formed at the national level play a decisive role. The ability of regional authorities to influence the development of the region comes down mainly to effective integration into the projects of the federal center.

\section{References}

Acemoglu, D., Johnson, S., \& Robinson, J. A. (2001a). Reversal of Fortune: Geography and Institutions in the Making of the Modern World Income Distribution, In NBER Working Papers, Working Paper, 8460. National Bureau of Economic Research. https://doi.org/10.3386/w8460

Acemoglu, D., Johnson, S., \& Robinson, J. A. (2001b). The Colonial Origins of Comparative Development: An Empirical Investigation, In American Economic Review, 91(5), 1369-1401. https://doi.org/10.1257/ aer.91.5.1369

Arellano-Yanguas, J. (2011). Aggravating the Resource Curse: Decentralisation, Mining and Conflict in Peru, In The Journal of Development Studies, 47(4), 617-638. https://doi.org/10.1080/00220381003706478

Belousova, S.V. (2015). Resursnye regiony: ekonomicheskie vozmozhnosti i finansovaia spravedlivost' [Resource regions: economic opportunities and financial justice], In Vserossiyskiy Ekonomicheskiy Zhurnal EKO [All-Russian Economic Journal ECO], 6 (492).

Borisov, V. V, Kruglov, V. V., Fedulov, A. S. (2012). Nechetkie modeli i seti [Fuzzy models and networks]. Moscow, 284 p.

Caselli, F., \& Michaels, G. (2013). Do Oil Windfalls Improve Living Standards? Evidence from Brazil, In American Economic Journal: Applied Economics, 5(1), 208-238. https://doi.org/10.1257/app.5.1.208

Cust, J., \& Rusli, R. D. (2014). The economic spillovers from resource extraction: A partial resource blessing at the subnational level? In Economic Growth Centre Working Paper Series (1402. Economic Growth Centre Working Paper Series). Nanyang Technological University, School of Social Sciences, Economic Growth Centre. https://ideas.repec.org/p/nan/wpaper/1402.html 
Dell, M., Jones, B. F., \& Olken, B. A. (2009). Temperature and Income: Reconciling New CrossSectional and Panel Estimates, In American Economic Review, 99(2), 198-204. https://doi.org/10.1257/ aer.99.2.198

Easterly, W., \& Levine, R. (2003). Tropics, germs, and crops: How endowments influence economic development, In Journal of Monetary Economics, 50(1), 3-39. https://doi.org/10.1016/S0304-3932(02)00200-3

Gennaioli, N., La Porta, R., Lopez-de-Silanes, F., \& Shleifer, A. (2013). Human Capital and Regional Development, In The Quarterly Journal of Economics, 128(1), 105-164. https://doi.org/10.1093/qje/qjs050

Glazyrina, I.P., Klevakina, E.A. (2013). Ekonomicheskii rost i neravenstvo po dokhodam v regionakh Rossii [Economic growth and income inequality in the regions of Russia], In Vserossiiskii Ekonomicheskii Zhurnal EKO [All-Russian Economic Journal ECO], 11, 113-128.

Ilyina, I.N. (2013). Perspektivy razvitiia syr'evykh regionov RF v dokumentakh strategicheskogo planirovaniia [Prospects for the development of raw materials regions of the Russian Federation in strategic planning documents]. In Voprosy Gosudarstvennogo i Munitsipal'nogo Upravleniya [Questions of state and municipal management], 2, 91-112.

Kagan, E.S., Goosen, E.V. (2017). Resursnye regiony: kachestvennye i kolichestvennye kriterii vydeleniia [Resource regions: qualitative and quantitative criteria for allocation], In Naukoemkie Tekhnologii Razrabotki i Ispol'zovaniya Mineral'nykh Resursov [Science-intensive technologies for the development and use of mineral resources], 3, 163-170.

Knack, S., \& Keefer, P. (1995). Institutions and Economic Performance: Cross-Country Tests Using Alternative Institutional Measures, In Economics \& Politics, 7(3), 207-227. https://doi. org/10.1111/j.1468-0343.1995.tb00111.x

Kurbatova, M. V., Levin, S. N., Kagan, E. S., Kislitsyn, D. V. (2019). Regiony resursnogo tipa v Rossii: opredelenie i klassifikatsiia [Resource-type regions in Russia: definition and classification], In Terra Economicus, 17(3), 89-106.

Kurbatova, M.V., Levin, S.N. (2010). Deformalizatsiia pravil v sovremennoi rossiiskoi ekonomike (na primere vzaimodeistviia vlasti i biznesa) [Deformalization of rules in the modern Russian economy (on the example of the interaction of government and business)], In Terra economicus, 8(1), $27-50$.

Levin, S. N., Kagan, Ye. S., \& Sablin, K. S. (2015). Regiony «resursnogo tipa» v sovremennoi rossiiskoi ekonomike [Resource-type regions in Russia: definition and classification], In Journal of Institutional Studies, 7(3), 92-101. https://doi.org/10.17835/2076-6297.2015.7.3.092-101

Mauro, P. (1995). Corruption and Growth, In The Quarterly Journal of Economics, 110(3), 681-712. https://doi.org/10.2307/2946696

Mitton, T. (2016). The wealth of subnations: Geography, institutions, and within-country development, In Journal of Development Economics, 118, 88-111. https://doi.org/10.1016/j.jdeveco.2015.09.002

Nordhaus, W. D. (2006). Geography and macroeconomics: New data and new findings, In Proceedings of the National Academy of Sciences, 103(10), 3510-3517. https:/doi.org/10.1073/pnas.0509842103

Onar, S. C., Oztaysi, B., \& Kahraman, C. (2018). A fuzzy rule based inference system for early debt collection, In Technological and Economic Development of Economy, 24(5), 1845-1865. https://doi.org/10. 3846/20294913.2016.1266409

Perry, G., \& Olivera, M. (2009). Natural resources, institutions and economic performance. A FEDESARROLLO Publication, November, 15.

Remmer, K. L., \& Wibbles, E. (2000). The Subnational Politics of Economic Adjustment: Provincial Politics and Fiscal Performance in Argentina, In Comparative Political Studies, 33(4), 419-451. https://doi. org/10.1177/0010414000033004001

Rodrik, D., Subramanian, A., \& Trebbi, F. (2004). Institutions Rule: The Primacy of Institutions Over Geography and Integration in Economic Development, In Journal of Economic Growth, 9(2), 131-165. https://doi.org/10.1023/B: JOEG.0000031425.72248.85

Sachs, J. D. (2001). Tropical Underdevelopment, In NBER Working Paper Series, Working Paper No. 8119. National Bureau of Economic Research. https://doi.org/10.3386/w8119 
Sachs, J. D., \& Warner, A. M. (1995). Natural Resource Abundance and Economic Growth (Working Paper No. 5398; Working Paper Series). National Bureau of Economic Research. https://doi.org/10.3386/ w5398

Van der Ploeg, F. (2011). Natural Resources: Curse or Blessing? In Journal of Economic Literature, 49(2), 366-420. https://doi.org/10.1257/jel.49.2.366

Warner, A. (2002). Institutions, Geography, Regions, Countries and the Mobility Bias. In CID Working Papers (91; CID Working Papers). Center for International Development at Harvard University, available at: https://ideas.repec.org/p/cid/wpfacu/91.html

Zubarevich, N.V. (2009). Regional'noe razvitie i regional'naia politika za desiatiletie ekonomicheskogo rosta [Regional development and regional policy for a decade of economic growth], In Zhurnal Novoi Ekonomicheskoi Assotsiatsii [Journal of a new economic association], 1-2, 160-174. 